\title{
Contribution of Double-strand Break Repair Gene Nijmegen Breakage Syndrome 1 Genotypes, Gender Difference and Smoking Status to Taiwanese Lung Cancer
}

\author{
CHIN-LIANG CHUANG ${ }^{1 *}$, CHUNG-HSING WANG ${ }^{2 *}$, CHANG-HSIEN HSU ${ }^{3 *}$, \\ CHIEH-LUN HSIAO ${ }^{2}$, GUAN-LIANG CHEN $^{1,4}$, SHIOU-TING YEN $^{2}$, HSIN-TING LI ${ }^{2}$, \\ WEN-SHIN CHANG ${ }^{2}$, CHIA-WEN TSAI ${ }^{2}$, SHOU-CHENG WANG ${ }^{1,5}$ and DA-TIAN BAU ${ }^{2,4,6}$ \\ ${ }^{1}$ Taichung Armed Forces General Hospital, Taichung, Taiwan, R.O.C.; \\ ${ }^{2}$ Terry Fox Cancer Research Laboratory, Department of Medical Research, \\ China Medical University Hospital, Taichung, Taiwan, R.O.C.; \\ ${ }^{3}$ Department of Business Administration, Asia University, Taichung, Taiwan, R.O.C.; \\ ${ }^{4}$ Graduate Institute of Biomedical Sciences, China Medical University, Taichung, Taiwan, R.O.C.; \\ ${ }^{5}$ National Defense Medical Center, Taipei, Taiwan, R.O.C.; \\ ${ }^{6}$ Department of Bioinformatics and Medical Engineering, Asia University, Taichung, Taiwan, R.O.C.
}

\begin{abstract}
Background/Aim: Nijmegen breakage syndrome 1 (NBS1) is a component of MRE11/RAD50/NBS1 complex $(M R N)$ that plays a critical role in the cellular response to DNA damage and maintenance of chromosomal integrity. Failure in DNA damage response affects the level of cell survival, increases the frequency of gene mutation or chromosomal instability and other cellular phenotypic abnormalities, which are the important mechanisms of carcinogenesis. However, the contribution of variant NBS1 genotypes to lung cancer is not known. The current study aimed to evaluate the contribution of the common variant NBS1 Glu185Gln (rs 1805794, E185Q) genotypes to the risk of lung cancer. Materials and Methods: The contributions of the NBS1 Glu185Gln genotypes to lung cancer risk were investigated among 358 patients with lung cancer and 716 age- and gender-matched healthy controls by polymerase chain reaction-restriction fragment length polymorphism (PCR-RFLP). Results: GG, CG and CC NBS1 Glu185Gln genotype percentages were $45.2 \%, 43.9 \%$ and $10.9 \%$ in the
\end{abstract}

\footnotetext{
*These Authors contributed equally to this study.

Correspondence to: Da-Tian Bau, Shou-Cheng Wang and Chia-Wen Tsai, Terry Fox Cancer Research Laboratory, Department of Medical Research, China Medical University Hospital, 2 Yuh-Der Road, Taichung, 404 Taiwan, R.O.C. Tel: +886 422052121 (Ext. 7534), e-mail: datian@mail.cmuh.org.tw; artbau2@gmail.com
}

Key Words: Double-strand break repair, gender, genotype, lung cancer, NBS1, polymorphism, smoking. patient group and $46.1 \%, 45.1 \%$ and $8.8 \%$ in the non-cancer control group, respectively ( $p$ for trend=0.5423). Analysis of allelic frequency distributions showed that the $C$ allele of NBS1 Glu185Gln did not increase lung cancer susceptibility $(p=0.4916)$. Interestingly, the CC genotypes at NBS1 Glu185Gln enhanced the risk of lung cancer among the males adjusted odds ratio $(a O R)=1.85$, 95\% confidence interval $(C I)=1.12-2.83$ and among the smokers $(a O R=1.76$, 95\% CI=1.09-2.64) but not among the females and nonsmokers. Conclusion: The CC genotype of NBS1 Glu185Gln may increase lung cancer risk only for males and smokers and may serve as a practical marker for early detective and predictive purposes of lung cancer.

For many years, lung cancer has been the leading cause of cancer-related mortality all over the world (1, 2). Even though many antitumor therapeutic strategies are being developed, the prognosis of patients with lung cancer remains poor, as the 5-year survival rate is still less than $20 \%$ (3). From the epidemiologic point of view, the most wellknown factor implicated in lung carcinogenesis is the individual long-term habit of tobacco consumption, which is also useful for prediction of prognosis $(4,5)$. Although cigarettes contain various kinds of carcinogens that may increase reactive oxygen species, DNA adducts and strand breaks in cells of lung and other organs, according to epidemiological reports, show that only $10-15 \%$ of all smokers actually develop lung cancer during their lifetime, indicating that individual susceptibility to carcinogens in cigarette smoke is unpredictable $(6,7)$. In this decade, lots of case-control studies have reported that specific genotypes 
are associated with higher lung cancer risk for cigarette smokers than non-smokers (8-15) and vice versa (16-19). These population studies elucidating the gene-lifestyle interactions on lung cancer risk, especially for smokers and non-smokers, may provide predictive systems for revealing the personalized etiology of lung cancer, personalized therapy and genomic pharmacology.

Our cells are exposed continuously to exogenous and endogenous DNA damage mechanisms, while the DNA repair system is critically responsible for removing all types of damage as soon as possible from our genome. Among the various kinds of DNA repair proteins, the DNA repair and telomere maintenance protein NBS1, named after the Nijmegen breakage syndrome gene (NBS1), contains three functional regions: the forkhead-associated (FHA) domain and BRCA1 C-terminus (BRCT) domain at the N-terminus, several SQ motifs (consensus phosphorylation sites by ATM and ATR kinases) at a central region and MRE11-binding region at the $\mathrm{C}$-terminus. In response to DNA damage, histone $\mathrm{H} 2 \mathrm{AX}$, in the vicinity of double-strand breaks (DSBs), is phosphorylated by ATM (20). NBS1 then targets the MRE11/RAD50 complex to the sites of DSBs through interaction of the FHA/BRCT domain with $\gamma$-H2AX (21). After that, NBS1 complex binds directly to the damaged DNA and the repair of DSB is initiated (22). In addition to fulfill the proper DSB repair processes, ATM also regulates cellcycle checkpoints at $\mathrm{G}_{1}, \mathrm{G}_{2}$ and intra-S phases via phosphorylation of SMC, CHK2 and FANCD2. The phosphorylation of these proteins also requires the involvement of NBS1 (23-25). Thus, NBS1 has at least two important roles in genome maintenance; as a DNA repair protein in the homologous recombination (HR) pathway and as a signal modifier in intra-S phase checkpoints. NBS1 is also known to be involved in maintenance of telomeres, which have DSB-like structures and defects here can cause telomeric fusion, genomic instability and aging deregulation $(26,27)$.

The NBS1 gene, located on human chromosome 8q21 (28), encodes the 754-amino acid protein NBS1 (29). In a previous animal study, higher susceptibility of cancer was detected among heterozygous $N b s \mathrm{H}+/-)$ mice (30), which suggested that mutation in the Nijmegen breakage syndrome gene might influence cancer development. One of the most commonly investigated polymorphisms was a $\mathrm{G}$ to $\mathrm{C}$ polymorphism leading to a substitution of glutamate (Glu) with glutamine (Gln). Known as Glu185Gln (rs1805794, E185Q), this polymorphism was widely studied on the association with susceptibility of cancers, such as breast (31), bladder (32), prostate (33), colorectal (34), leukemia (35) and nasopharyngeal cancer (36). As for lung cancer, there were also several reports that investigated the contribution of NBS1 genotypes to lung cancer susceptibility (37-39). However, the results reported by these studies remained inconsistent. In the current study, we aimed to investigate the contribution of NBS1 genotypes at Glu185Gln (rs1805794, E185Q) single-nucleotide polymorphic (SNP) site to the risk of lung cancer and, then, examine the joint effect of smoking habit and NBS1 Glu185Gln genotypes on lung cancer risk in Taiwan.

\section{Materials and Methods}

Investigated population. Three hundred and fifty-eight patients diagnosed with lung cancer were recruited by the surgery team at the Outpatient Clinics of General Surgery at the China Medical University Hospital during 2005-2008. The clinical characteristics of patients, including histological details, were all graded and defined by expert surgeons. The patients with history of any other cancer and pulmonary diseases, such as chronic obstructive pulmonary disease (COPD), pneumothorax and asthma, were excluded from the databank. All participants voluntarily completed a self-administered questionnaire and provided a 3- to 5-ml sample of peripheral blood. At the same time, twice as many non-lung cancer healthy volunteers as controls were selected by matching for age, gender and smoking behavior after initial random sampling from the Health Examination Cohort of China Medical University Hospital. The exclusion criteria of the controls included previous malignancy, metastasized cancer from other or unknown origin and any genetic or familial diseases. The study was approved by the Institutional Review Board of the China Medical University Hospital with the document coded DMR100-IRB-284 and written informed consent was obtained from all participants. Several selected characteristics of the subjects collected in this study are summarized in Table I.

Genotyping conditions. Genomic DNA from peripheral blood leucocytes of each patient and controls was prepared using the QIAamp Blood Mini Kit (Blossom, Taipei, Taiwan) and further stored and processed as previously described (40-42). The polymerase chain reaction (PCR) cycling programs for NBS1 genotypes were: one cycle at $94^{\circ} \mathrm{C}$ for $5 \mathrm{~min} ; 35$ cycles of $94^{\circ} \mathrm{C}$ for $30 \mathrm{~s}, 55^{\circ} \mathrm{C}$ for $30 \mathrm{~s}$ and $72^{\circ} \mathrm{C}$ for $30 \mathrm{~s}$; and a final extension at $72^{\circ} \mathrm{C}$ for $10 \mathrm{~min}$. The sequences of forward and reverse primers for NBS1 Glu185Gln genotyping work were 5'-TGTGCTCTTCTG ACCATGAG-3' and 5'-CAGTGACCAAAGACCGACTT-3', respectively. The PCR products were subject to restriction enzyme Hinf I (New England BioLabs, Ipswich, MA, USA). The digestible $\mathrm{C}$ allele was cut into 321- and 255-base pair contigs, while indigestible $\mathrm{G}$ allele was of intact 576-base pair long contig. The genotypic process was performed by two researchers independently and blindly. Five percent of the samples for NBS1 Glu185Gln were randomly selected for direct sequencing and the results from PCRrestriction fragment length polymorphism analysis and direct sequencing were $100 \%$ concordant.

Statistical analyses. Seven hundred and sixteen of the controls and 358 cases with genotypic and clinical data were analyzed. To ensure that the controls used were representative of the general population and to exclude the possibility of genotyping error, the deviation of the genotype frequencies of NBS1 SNP in the controls from those expected under the Hardy-Weinberg equilibrium was assessed using the goodness-of-fit test. Pearson's Chi-square test was used to compare the distribution of the NBS1 genotypes between the cases and the controls. The associations between the NBS1 genotypes and 
Table I. Distribution of selected demographic data of the 358 patients with lung cancer and the 716 matched controls.

\begin{tabular}{|c|c|c|c|c|c|c|c|}
\hline \multirow[t]{2}{*}{ Characteristics } & \multicolumn{3}{|c|}{ Controls ( $\mathrm{n}=716)$} & \multicolumn{3}{|c|}{ Patients $(\mathrm{n}=358)$} & \multirow[t]{2}{*}{$p$-Value ${ }^{a}$} \\
\hline & $\mathrm{n}$ & $\%$ & Mean (SD) & $\mathrm{n}$ & $\%$ & Mean (SD) & \\
\hline Age (years) & & & $64.8(6.8)$ & & & $64.0(6.9)$ & 0.5871 \\
\hline Gender & & & & & & & 0.3642 \\
\hline Male & 488 & $68.1 \%$ & & 254 & $70.9 \%$ & & \\
\hline Female & 228 & $31.9 \%$ & & 104 & $29.1 \%$ & & 0.3642 \\
\hline \multicolumn{8}{|l|}{ Smoking status } \\
\hline Ever smokers & 563 & $78.6 \%$ & & 293 & $81.8 \%$ & & \\
\hline Non-smokers & 153 & $21.4 \%$ & & 65 & $18.2 \%$ & & 0.2282 \\
\hline \multicolumn{8}{|l|}{ Histology } \\
\hline Adenocarcinoma & & & & 218 & $60.9 \%$ & & \\
\hline SCC & & & & 106 & $29.6 \%$ & & \\
\hline Other & & & & 34 & $9.5 \%$ & & \\
\hline
\end{tabular}

aBased on Chi-square test, SCC, Squamous cell carcinoma; SD, standard deviation.

Table II. Distribution of NBS1 Glu185Gln genotypes among the 358 patients with lung cancer and the 716 matched controls.

\begin{tabular}{|c|c|c|c|c|c|c|}
\hline \multirow[t]{2}{*}{ Glu185Gln } & \multicolumn{2}{|c|}{ Controls } & \multicolumn{2}{|c|}{ Patients } & \multirow[t]{2}{*}{ OR $(95 \% \mathrm{CI})$} & \multirow[t]{2}{*}{$p$-Value ${ }^{\mathrm{a}}$} \\
\hline & $\mathrm{n}$ & $\%$ & $\mathrm{n}$ & $\%$ & & \\
\hline \multicolumn{7}{|l|}{ Genotype } \\
\hline GG & 330 & $46.1 \%$ & 162 & $45.2 \%$ & 1.00 (reference) & \\
\hline CG & 323 & $45.1 \%$ & 157 & $43.9 \%$ & $0.99(0.76-1.29)$ & 0.9422 \\
\hline $\mathrm{CC}$ & 63 & $8.8 \%$ & 39 & $10.9 \%$ & $1.26(0.81-1.96)$ & 0.3024 \\
\hline$P_{\text {trend }}$ & & & & & & 0.5423 \\
\hline \multicolumn{7}{|c|}{ Carrier analysis } \\
\hline GG+CG & 653 & $91.2 \%$ & 319 & $89.1 \%$ & 1.00 (reference) & \\
\hline $\mathrm{CC}$ & 63 & $8.8 \%$ & 39 & $10.9 \%$ & $1.27(0.83-1.93)$ & 0.3307 \\
\hline GG & 330 & $46.1 \%$ & 162 & $45.2 \%$ & 1.00 (reference) & \\
\hline $\mathrm{CG}+\mathrm{CC}$ & 386 & $53.9 \%$ & 196 & $54.8 \%$ & $1.03(0.80-1.33)$ & 0.7950 \\
\hline
\end{tabular}

aBased on chi-square test without Yates' correction; * $p<0.05$. OR, Odds ratio; CI, confidence interval.

lung cancer risk were estimated by computing odds ratios (ORs) and their $95 \%$ confidence intervals (CIs) from logistic regression analysis. A value of $p<0.05$ was considered statistically significant.

\section{Results}

The frequency distributions of demographic characteristics, such as age, gender and smoking status, for the 358 patients with lung cancer and 716 non-cancer controls are summarized in Table I. The average age of the patients was 64.0 years, non-significantly different from 64.8 years of the controls, while the ratio of male versus female lung cancer patients was about 7:3 (Table I). Since we applied frequency matching to recruit the non-cancer healthy controls, there was no difference in the distributions of age and gender between the control and case groups (Table I). From the histological point of view, the percentages of adenocarcinoma, squamous cell carcinoma and patients of other histology were $60.9 \%, 29.6 \%$ and $9.5 \%$, respectively (Table I).

The distributions of the NBS1 genotypes at Glu185Gln among the non-cancer controls and the patients with lung cancer are presented and statistically analyzed in Table II. The genotypes of NBS1 Glu185Gln were not differently distributed between lung cancer and non-cancer control groups ( $p$ for trend $=0.5423$ ) (Table II). In detail, NBS1 Glu185Gln heterozygous CG was not associated with lung cancer risk $(\mathrm{OR}=0.99,95 \% \mathrm{CI}=0.76-1.29, p=0.9422)$, while the homozygous $\mathrm{CC}$ genotype seemed to be only slightly associated with increased lung cancer risk $(\mathrm{OR}=1.26,95 \%$ $\mathrm{CI}=0.81-1.96, p=0.3024)$ but not statistically significant 
Table III. Distribution of NBS1 Glu185Gln allelic frequencies among the 358 patients with lung cancer and the 716 matched controls.

\begin{tabular}{rcccccc}
\hline & Controls & $\%$ & Patients & $\%$ & OR (95\% CI) & $p$-Value \\
\hline Glu185Gln & & & & & & \\
Allele G & 983 & $68.6 \%$ & 481 & $67.2 \%$ & 1.00 (reference) \\
Allele C & 449 & $31.4 \%$ & 235 & $32.8 \%$ & $1.07(0.88-1.30)$ & 0.4916 \\
\hline
\end{tabular}

aBased on chi-square test; ${ }^{*} p<0.05$. *Statistically significant. OR, Odds ratio; CI, confidence interval.

Table IV. Odds ratios for NBS1 Glu185Gln genotype and lung cancer after stratified by gender.

\begin{tabular}{|c|c|c|c|c|c|c|}
\hline \multirow[t]{2}{*}{ Genotypes } & \multicolumn{2}{|c|}{ Males } & \multirow[t]{2}{*}{$\mathrm{aOR}(95 \% \mathrm{CI})^{\mathrm{a}}$} & \multicolumn{2}{|c|}{ Females } & \multirow[t]{2}{*}{$\mathrm{aOR}(95 \% \mathrm{CI})^{\mathrm{a}}$} \\
\hline & Controls & Cases & & Controls & Cases & \\
\hline GG & 235 & 116 & 1.00 (Reference) & 95 & 46 & 1.00 (Reference) \\
\hline CG & 214 & 105 & $1.04(0.73-1.46)$ & 109 & 52 & $0.97(0.63-1.62)$ \\
\hline $\mathrm{CC}$ & 39 & 33 & $1.85(1.12-2.83)^{*}$ & 24 & 6 & $0.64(0.26-1.34)$ \\
\hline Total & 488 & 254 & & 228 & 104 & \\
\hline
\end{tabular}

aThe aORs were estimated with multivariate logistic regression analysis after adjusted for age, smoking, alcohol drinking and areca chewing habits. *Statistical significant. aOR, Adjusted odds ratio; CI, confidence interval.

Table V. Odds ratios for NBS1 Glu185Gln genotype and lung cancer after stratified by smoking status.

\begin{tabular}{|c|c|c|c|c|c|c|}
\hline \multirow[t]{2}{*}{ Genotypes } & \multicolumn{2}{|c|}{ Non-smokers } & \multirow[t]{2}{*}{$\mathrm{aOR}(95 \% \mathrm{CI})^{\mathrm{a}}$} & \multicolumn{2}{|c|}{ Smokers } & \multirow[t]{2}{*}{$\mathrm{aOR}(95 \% \mathrm{CI})^{\mathrm{a}}$} \\
\hline & Controls & Cases & & Controls & Cases & \\
\hline GG & 68 & 28 & 1.00 (Reference) & 262 & 134 & 1.00 (Reference) \\
\hline CG & 64 & 32 & $1.19(0.64-2.13)$ & 259 & 125 & $1.06(0.73-1.35)$ \\
\hline $\mathrm{CC}$ & 21 & 5 & $0.82(0.36-1.86)$ & 42 & 34 & $1.76(1.09-2.64)^{*}$ \\
\hline Total & 153 & 65 & & 563 & 293 & \\
\hline
\end{tabular}

aThe aORs (odds ratios) were estimated with multivariate logistic regression analysis after adjusted for age, gender, alcohol drinking and areca chewing habits. *Statistical significant. aOR, Adjusted odds ratio; CI, confidence interval.

(Table III). The results of carrier analysis indicated that, in both dominant and recessive models, the differential distribution of genotypes were not so obvious between the lung cancer and control groups (Table III).

To confirm the findings of Table III, analysis of allelic frequency distribution for the NBS1 Glu185Gln was also conducted, with the results being summarized in Table IV. Supporting the findings that neither heterozygous CG nor homozygous CC genotype of NBS1 Glu185Gln was associated with increased lung cancer risk, the $\mathrm{C}$ allele was not significantly more frequently higher in cases than in controls $(p=0.4916)$ (Table III).

The joint effects of NBS1 Glu185Gln with gender and smoking status were examined (Tables IV and V). First, lung cancer patients and controls were stratified according to their gender and ORs were analyzed. The results showed that males carrying the homologous CC genotypes at NBSI Glu185Gln were of increased risk of lung cancer after adjusted for age, smoking, alcohol drinking and areca chewing habits (adjusted $\mathrm{OR}[\mathrm{aOR}]=1.85,95 \% \mathrm{CI}=1.12-2.83$ ) (Table IV). On the contrary, there was no significantly elevated lung cancer risk for females with CG or CC genotypes at NBS1 Glu185Gln (Table IV). Second, lung cancer patients and controls were stratified according to their smoking status and ORs were analyzed. The results showed that ever-smokers carrying the homologous CC genotypes at NBSl Glu185Gln were of increased risk of lung cancer after adjusted for age, gender, alcohol drinking and areca chewing habits $(\mathrm{aOR}=1.76,95 \%$ 
$\mathrm{CI}=1.09-2.64)($ Table V). On the contrary, there was no significantly elevated lung cancer risk for non-smokers with CG or CC genotypes at NBSl Glu185Gln (Table V).

\section{Discussion}

NBS1 plays pivotal roles in maintaining genomic stability and the initiation and progression of carcinogenesis. The exon variantrs1805794 (Glu185Gln) of NBS1 has been studied in case-control association studies. However, the results were conflicting. In the current case-control association study in Taiwan, the contribution of NBSI Glu185Gln genotype, gender and smoking status to lung cancer risk was evaluated. Among lung cancer patients and non-cancer healthy control subjects, the genotyping results showed that neither heterozygous CG nor homozygous CC genotypes of $N B S 1$ Glu185Gln was significantly associated with an increased risk of lung cancer (Table II). The allelic frequency analysis supports the findings from genotypic frequency analysis that the $\mathrm{C}$ allele of $N B S 1$ Glu185Gln was not associated with an increased lung cancer risk (Table III). This negative association has also been evident from several studies $(37,43,44)$. On the contrary, there were two reports with positive association. In 2010, Fan and co-workers found that, compared to the GG genotype, the $\mathrm{C}$ genotypes (CG/CC) at NBS1 Glu185Gln conferred a significantly 1- to 46-fold increased OR of lung cancer (45). Similar positive association was proposed by Fang and colleagues reporting that, compared to the GG genotype, the $\mathrm{C}$ genotypes (CG/CC) at NBS1 Glu185Gln conferred a significantly increased risk of lung cancer in a Chinese cohort $(\mathrm{OR}=1.40)$. They have also investigated the contribution of this polymorphism with phenotypic assays and shown that X-ray radiation induced more chromatid breaks in lymphocyte cells from $\mathrm{C}$ genotype individuals than those from the GG genotype carriers (46). Noticeably, the current findings, as well as others, all showed that the $\mathrm{C}$ allele of NBSI Glu $185 \mathrm{Gln}$ is slightly positively associated with an increased lung cancer risk; however, further validations in larger and different populations are needed.

Gender is a risk factor for lung cancer. Although the mechanism(s) explaining this gender-dependent difference in lung cancer risk is not known, it is thought that endocrine factors may play a critical role (47). In the National Health Insurance Research Database of Taiwan, investigating 33,919 patients with lung cancer recorded from 2002 to 2008 in Taiwan, about two-thirds of patients were males (48), with the ratio being very similar to the gender ratio of this study. During recent years, there has been an increasing trend for female patients with lung cancer in Taiwan as the prevalence and mortality rates of females with non-small cell lung cancer adenocarcinoma are very high in Taiwan. Therefore, we were interested whether the genotype of NBSI
Glu185Gln contributes to the gender difference in lung cancer susceptibility. After stratification by gender, it was found that the genotypes of NBSI Glu185Gln were differently distributed among males but not among females (Table IV). One explanation for the trend for female patients with lung cancer is the increase of cigarette consumption. The results of epidemiological studies suggest that, after one can control the number of cigarettes smoked, women have a three-time higher risk of suffering lung cancer than men (47).

As mentioned above, smoking is another well-known risk factor for lung cancer. Cigarette smoke may enhance remodeling in the developing human airway smooth muscle through hyperplasia and alteration of extracellular microenvironment, thus contributing to the development of neonatal and pediatric airway disease (49). In addition, tobacco smoking can induce DNA lesions and defects in repair of tobacco carcinogen-induced DNA adducts may contribute to carcinogenesis (50). Therefore, the interaction of the genotype of NBS1 Glu185Gln and cigarette smoking status of the participants was also analyzed. As expected, the results showed that the genotypic distribution of the variant genotypes of $N B S 1$ Glu185Gln was significantly different between lung cancer and control sub-groups who were ever smokers (Table V). On the contrary, no differential distribution was observed among non-smokers (Table V). There was a phenotypic assay showing that the rs1805794C allele attenuated NBS1's capacity to remove DNA damage as cells transfected with a plasmid carrying the rs $1805794 \mathrm{C}$ allele had significantly higher DNA breaks than those transfected with a plasmid carrying the rs $1805794 \mathrm{G}$ allele after X-ray irradiation (46). Further investigations using cells from patients rather than cell lines should be conducted to explore the joint effects of tobacco smoking, other risk factors and this polymorphism on cancer risk. Likewise, future investigations should be designed based on cells from different gender, drinking status and other lung cancer risk factors.

In conclusion, our study provides evidence that the $\mathrm{C}$ allele of NBS1 Glu185Gln is associated with an increased lung cancer risk among males, especially smokers.

\section{Conflicts of Interest}

The Authors declare no conflicts of interest.

\section{Acknowledgements}

The Authors are grateful to Tissue-bank of China Medical University Hospital and doctors/nurses under Professor Hsia's leadership for their excellent sample collection and technical assistance. This study was supported partially by research grants from Taichung Armed Forces General Hospital (106A06) to Chuang, from Asia University (ASIA-105-CMUH-11) to Hsu and from Taiwan Ministry of Health and Welfare Clinical Trial and Research Center of Excellence (MOHW106-TDU-B-212-113004). 


\section{References}

1 Siegel RL, Miller KD and Jemal A: Cancer statistics, 2015. CA Cancer J Clin 65: 5-29, 2015.

2 Torre LA, Bray F, Siegel RL, Ferlay J, Lortet-Tieulent J and Jemal A: Global cancer statistics, 2012. CA Cancer J Clin 65: 87-108, 2015

3 Li Z, Chen L and Qin Z: Paradoxical roles of IL-4 in tumor immunity. Cell Mol Immunol 6: 415-422, 2009.

4 Hasegawa Y, Ando M, Maemondo M, Yamamoto S, Isa S, Saka H, Kubo A, Kawaguchi T, Takada M, Rosell R, Kurata T and Ou $\mathrm{SH}$ : The role of smoking status on the progression-free survival of non-small cell lung cancer patients harboring activating epidermal growth factor receptor (EGFR) mutations receiving first-line EGFR tyrosine kinase inhibitor versus platinum doublet chemotherapy: A meta-analysis of prospective randomized trials. Oncologist 20: 307-315, 2015.

5 Bhatt VR, Batra R, Silberstein PT, Loberiza FR, Jr. and Ganti AK: Effect of smoking on survival from non-small cell lung cancer: A retrospective Veterans' Affairs Central Cancer Registry (VACCR) cohort analysis. Med Oncol 32: 339, 2015.

6 Shields PG and Harris CC: Cancer risk and low-penetrance susceptibility genes in gene-environment interactions. J Clin Oncol 18: 2309-2315, 2000.

7 Shields PG: Molecular epidemiology of smoking and lung cancer. Oncogene 21: 6870-6876, 2002.

8 Ji YN, Wang Q and Suo LJ: CYP1A1 Ile462Val polymorphism contributes to lung cancer susceptibility among lung squamous carcinoma and smokers: A meta-analysis. PLoS One 7: e43397, 2012.

9 Spitz MR, Gorlov IP, Dong Q, Wu X, Chen W, Chang DW, Etzel CJ, Caporaso NE, Zhao Y, Christiani DC, Brennan P, Albanes D, Shi J, Thun M, Landi MT and Amos CI: Multistage analysis of variants in the inflammation pathway and lung cancer risk in smokers. Cancer Epidemiol Biomarkers Prev 21: 1213-1221, 2012.

10 Hsia TC, Chang WS, Liang SJ, Chen WC, Tu CY, Chen HJ, Yang MD, Tsai CW, Hsu CM, Tsai CH and Bau DT: Interleukin-10 (IL10) promoter genotypes are associated with lung cancer risk in Taiwan males and smokers. Anticancer Res 34: 7039-7044, 2014.

11 Hsia TC, Chang WS, Chen WC, Liang SJ, Tu CY, Chen HJ, Liang JA, Tsai CW, Hsu CM, Tsai CH and Bau DT: Genotype of DNA double-strand break repair gene XRCC7 is associated with lung cancer risk in Taiwan males and smokers. Anticancer Res 34: 7001-7005, 2014.

12 Hsia TC, Tsai CW, Liang SJ, Chang WS, Lin LY, Chen WC, Tu $\mathrm{CY}$, Tsai $\mathrm{CH}$ and Bau DT: Effects of ataxia telangiectasia mutated (ATM) genotypes and smoking habits on lung cancer risk in Taiwan. Anticancer Res 33: 4067-4071, 2013.

13 Chen X, Lu H, Zhao M, Tashiro K, Cassis LA and Daugherty A: Contributions of leukocyte angiotensin-converting enzyme to development of atherosclerosis. Arterioscler Thromb Vasc Biol 33: 2075-2080, 2013.

14 Liu CJ, Hsia TC, Tsai RY, Sun SS, Wang CH, Lin CC, Tsai CW, Huang CY, Hsu CM and Bau DT: The joint effect of hOGG1 single nucleotide polymorphism and smoking habit on lung cancer in Taiwan. Anticancer Res 30: 4141-4145, 2010.

15 Liu CJ, Hsia TC, Wang RF, Tsai CW, Chu CC, Hang LW, Wang $\mathrm{CH}$, Lee HZ, Tsai RY and Bau DT: Interaction of cyclooxygenase 2 genotype and smoking habit in Taiwanese lung cancer patients. Anticancer Res 30: 1195-1199, 2010.
16 Govindan R: Lung cancer in never smokers: A new hot area of research. Lancet Oncol 11: 304-305, 2010.

17 Liu YL, Xu Y, Li F, Chen H and Guo SL: CYP2A6 deletion polymorphism is associated with decreased susceptibility of lung cancer in Asian smokers: A meta-analysis. Tumour Biol 34: 2651-2657, 2013.

18 Lo YL, Hsiao CF, Jou YS, Chang GC, Tsai YH, Su WC, Chen KY, Chen YM, Huang MS, Hsieh WS, Chen CJ and Hsiung CA: Polymorphisms of MLH1 and MSH2 genes and the risk of lung cancer among never smokers. Lung Cancer 72: 280286, 2011.

19 Wu X, Wang L, Ye Y, Aakre JA, Pu X, Chang GC, Yang PC, Roth JA, Marks RS, Lippman SM, Chang JY, Lu C, Deschamps C, Su WC, Wang WC, Huang MS, Chang DW, Li Y, Pankratz VS, Minna JD, Hong WK, Hildebrandt MA, Hsiung CA and Yang P: Genome-wide association study of genetic predictors of overall survival for non-small cell lung cancer in never smokers. Cancer Res 73: 4028-4038, 2013.

20 Burma S, Chen BP, Murphy M, Kurimasa A and Chen DJ: ATM phosphorylates histone H2AX in response to DNA double-strand breaks. J Biol Chem 276: 42462-42467, 2001.

21 Kobayashi J, Tauchi H, Sakamoto S, Nakamura A, Morishima $\mathrm{K}$, Matsuura S, Kobayashi T, Tamai K, Tanimoto $\mathrm{K}$ and Komatsu K: NBS1 localizes to gamma-H2AX foci through interaction with the FHA/BRCT domain. Curr Biol 12: 18461851, 2002.

22 Takeda S, Hoa NN and Sasanuma H: The role of the Mre11Rad50-Nbs1 complex in double-strand break repair-facts and myths. J Radiat Res 57(Suppl 1): i25-i32, 2016.

23 Kitagawa R, Bakkenist CJ, McKinnon PJ and Kastan MB: Phosphorylation of SMC1 is a critical downstream event in the ATM-NBS1-BRCA1 pathway. Genes Dev 18: 1423-1438, 2004.

24 Lee JH and Paull TT: Activation and regulation of ATM kinase activity in response to DNA double-strand breaks. Oncogene 26: 7741-7748, 2007.

25 Nakanishi K, Taniguchi T, Ranganathan V, New HV, Moreau LA, Stotsky M, Mathew CG, Kastan MB, Weaver DT and D'Andrea AD: Interaction of FANCD2 and NBS1 in the DNA damage response. Nat Cell Biol 4: 913-920, 2002.

26 Zhang Y, Zhou J and Lim CU: The role of NBS1 in DNA double strand break repair, telomere stability, and cell cycle checkpoint control. Cell Res 16: 45-54, 2006.

27 Matsuura S, Kobayashi J, Tauchi H and Komatsu K: Nijmegen breakage syndrome and DNA double strand break repair by NBS1 complex. Adv Biophys 38: 65-80, 2004.

28 Matsuura S, Tauchi H, Nakamura A, Kondo N, Sakamoto S, Endo S, Smeets D, Solder B, Belohradsky BH, Der Kaloustian VM, Oshimura M, Isomura M, Nakamura Y and Komatsu K: Positional cloning of the gene for Nijmegen breakage syndrome. Nat Genet 19: 179-181, 1998.

29 Carney JP, Maser RS, Olivares H, Davis EM, Le Beau M, Yates JR, 3rd, Hays L, Morgan WF and Petrini JH: The hMre11/hRad50 protein complex and Nijmegen breakage syndrome: Linkage of double-strand break repair to the cellular DNA damage response. Cell 93: 477-486, 1998.

30 Dumon-Jones V, Frappart PO, Tong WM, Sajithlal G, Hulla W, Schmid G, Herceg Z, Digweed $M$ and Wang ZQ: Nbn heterozygosity renders mice susceptible to tumor formation and ionizing radiation-induced tumorigenesis. Cancer Res 63: 72637269, 2003. 
31 Forsti A, Angelini S, Festa F, Sanyal S, Zhang Z, Grzybowska E, Pamula J, Pekala W, Zientek H, Hemminki K and Kumar R: Single nucleotide polymorphisms in breast cancer. Oncol Rep 11: 917-922, 2004.

32 Broberg K, Bjork J, Paulsson K, Hoglund M and Albin M: Constitutional short telomeres are strong genetic susceptibility markers for bladder cancer. Carcinogenesis 26: 1263-1271, 2005.

33 Hebbring SJ, Fredriksson H, White KA, Maier C, Ewing C, McDonnell SK, Jacobsen SJ, Cerhan J, Schaid DJ, Ikonen T, Autio V, Tammela TL, Herkommer K, Paiss T, Vogel W, Gielzak M, Sauvageot J, Schleutker J, Cooney KA, Isaacs W and Thibodeau SN: Role of the Nijmegen breakage syndrome 1 gene in familial and sporadic prostate cancer. Cancer Epidemiol Biomarkers Prev 15: 935-938, 2006.

34 Gil J, Ramsey D, Stembalska A, Karpinski P, Pesz KA, Laczmanska I, Leszczynski P, Grzebieniak Z and Sasiadek MM: The C/A polymorphism in intron 11 of the XPC gene plays a crucial role in the modulation of an individual's susceptibility to sporadic colorectal cancer. Mol Biol Rep 39: 527-534, 2012.

$35 \mathrm{Li} \mathrm{N}, \mathrm{Xu}$ Y, Zheng J, Jiang L, You Y, Wu H, Li W, Wu D and Zhou Y: NBS1 rs1805794G $>$ C polymorphism is associated with decreased risk of acute myeloid leukemia in a Chinese population. Mol Biol Rep 40: 3749-3756, 2013.

36 Zheng J, Zhang C, Jiang L, You Y, Liu Y, Lu J and Zhou Y: Functional NBS1 polymorphism is associated with occurrence and advanced disease status of nasopharyngeal carcinoma. Mol Carcinog 50: 689-696, 2011.

37 Ryk C, Kumar R, Thirumaran RK and Hou SM: Polymorphisms in the DNA repair genes XRCC1, APEX1, XRCC3 and NBS1, and the risk for lung cancer in never- and ever-smokers. Lung Cancer 54: 285-292, 2006.

38 Park SL, Bastani D, Goldstein BY, Chang SC, Cozen W, Cai L, Cordon-Cardo C, Ding B, Greenland S, He N, Hussain SK, Jiang Q, Lee YC, Liu S, Lu ML, Mack TM, Mao JT, Morgenstern H, Mu LN, Oh SS, Pantuck A, Papp JC, Rao J, Reuter VE, Tashkin DP, Wang $\mathrm{H}$, You NC, Yu SZ, Zhao JK and Zhang ZF: Associations between NBS1 polymorphisms, haplotypes and smoking-related cancers. Carcinogenesis 31: 1264-1271, 2010.

39 Zhao JW, Ling XX, Yang L: Association of polymorphism $8360 \mathrm{G}>\mathrm{C}$ in NBS1 gene and the risk of lung cancer in southern Chinese population. Acad J Guangzhou Med Coll 39: 5-8, 2011.

40 Pei JS, Hsu PC, Chou AK, Tsai CW, Chang WS, Hsiao CL, Hsu YN, Cheng SP and Bau DT: Matrix metalloproteinase-1 genotype contributes to the risk of non-solid tumor in childhood leukemia. Anticancer Res 36: 5127-5132, 2016.
41 Chang WS, Liao CH, Tsai CW, Hu PS, Wu HC, Hsu SW, Hsiao CL, Hsu CH, Hung YW and Bau DT: Association of enhancer of zeste 2 (EZH2) genotypes with bladder cancer risk in Taiwan. Anticancer Res 36: 4509-4514, 2016.

42 Pei JS, Chang WS, Hsu PC, Tsai CW, Hsu CM, Ji HX, Hsiao CL, Hsu YN and Bau DT: The association of flap endonuclease 1 genotypes with the risk of childhood leukemia. Cancer Genomics Proteomics 13: 69-74, 2016.

43 Lan Q, Shen M, Berndt SI, Bonner MR, He X, Yeager M, Welch $\mathrm{R}$, Keohavong P, Donahue M, Hainaut P and Chanock S: Smoky coal exposure, NBS1 polymorphisms, p53 protein accumulation, and lung cancer risk in Xuan Wei, China. Lung Cancer 49: 317323, 2005.

44 Zienolddiny S, Campa D, Lind H, Ryberg D, Skaug V, Stangeland L, Phillips DH, Canzian F and Haugen A: Polymorphisms of DNA repair genes and risk of non-small cell lung cancer. Carcinogenesis 27: 560-567, 2006.

45 Fan LH, Chen JL and Cai L: Study on the association between DNA double-strand break repair gene NBS1 polymorphisms and susceptibility on lung cancer. Zhonghua Liu Xing Bing Xue Za Zhi 31: 213-217, 2010.

46 Fang W, Qiu F, Zhang L, Deng J, Zhang H, Yang L, Zhou Y and $\mathrm{Lu} \mathrm{J}$ : The functional polymorphism of NBS1 p.Glu185Gln is associated with an increased risk of lung cancer in Chinese populations: Case-control and a meta-analysis. Mutat Res 770: 61-68, 2014.

47 Gasperino J: Gender is a risk factor for lung cancer. Med Hypotheses 76: 328-331, 2011.

48 Wang BY, Huang JY, Cheng CY, Lin CH, Ko J and Liaw YP: Lung cancer and prognosis in Taiwan: A population-based cancer registry. J Thorac Oncol 8: 1128-1135, 2013.

49 Vogel ER, VanOosten SK, Holman MA, Hohbein DD, Thompson MA, Vassallo R, Pandya HC, Prakash YS and Pabelick CM: Cigarette smoke enhances proliferation and extracellular matrix deposition by human fetal airway smooth muscle. Am J Physiol Lung Cell Mol Physiol 307: L978-L986, 2014.

50 Wei Q, Cheng L, Amos CI, Wang LE, Guo Z, Hong WK and Spitz MR: Repair of tobacco carcinogen-induced DNA adducts and lung cancer risk: A molecular epidemiologic study. J Natl Cancer Inst 92: 1764-1772, 2000.

Received March 10, 2017

Revised March 18, 2017

Accepted March 202017 